\title{
ВИДЫ НАКАЗАНИЯ, НАЗНАЧАЕМЫЕ НЕСОВЕРШЕННОЛЕТНИМ, ПО УГОЛОВНОМУ КОДЕКСУ ВЬЕТНАМА 2015 ГОДА
}

\author{
Нгуен Тху Чанг \\ аспирант \\ ФГАОУ ВО «Российский университет \\ дружбы народов»
}

\begin{abstract}
Аннотация: Уголовная ответственность несовершеннолетних всегда является одной из важных тем любого государства, в том числе Вьетнама. В статье рассматривается вопрос о видах наказания, применяемых к лицам в возрасте до 18-летнего возраста, согласно законодательству Вьетнама. В данной работе автор также сравнил положения нового уголовного кодекса 2005 года с уголовным кодексом 1999 года с целью выявления изменений в политике в отношении несовершеннолетних.
\end{abstract}

Ключевые слова: Наказание, несовершеннолетний, уголовный кодекс, право, Вьетнам.

\section{PUNISHMENTS IMPOSED UPON JUVENILE OFFENDERS UNDER THE 2015 CRIMINAL CODE OF VIETNAM}

\section{Nguyen Thu Trang}

\begin{abstract}
The criminal liability of minors is always one of the essential topics of any state, including Vietnam. The article deals with the issue of the types of punishment applied to persons under the age of 18, according to the legislation of Vietnam. In this paper, the author also compared the provisions of the new Criminal Code of 2005 with the Criminal Code of 1999 in order to identify changes in the policy towards minors.
\end{abstract}

Key words: Punishment, juvenile, criminal code, law, Viet Nam.

В истории уголовно-правовых рассуждений существует множество различных взглядов на понятие наказания. Однако эти взгляды в основном сосредоточены в двух направлениях: (1) либо рассматривать наказание как инструмент государственной мести, (2) либо рассматривать наказание как 
инструмент в борьбе с преступлениями. Мнение о том, что наказание является местью со стороны государства, основано на карательной доктрине, разработанной Кантом с идеей абсолютной справедливости. [2, С. 292] С этой точки зрения наказание определяется как боль (физическая либо психическая) или определенные ограничения, предоставляемые осужденному, по приговору или решению суда. [9, С.221]

Лица, не достигшие 18-летнего возраста, в уголовном праве именуются несовершеннолетними. Поскольку они не обладают полной осведомленностью и не были зрелыми при контроле над своим поведением, «обращуение с лицами моложе 18 лет, совершившими преступления, должно обеспечивать их наилучшие интересы и, главным образом, с цуелью обучения и помощи им в исправлении своих ошибок, в здоровом развитии и становлении полезньми гражданами для общества.» [3, п.1 ст.91]

Лица, не достигшие 18-летнего возраста, привлекаются к уголовной ответственности только в случаях необходимости, когда воспитательные и реабилитационные мероприятия не оказывают большого влияния. В рамках общей системы наказаний наказания, применяемые к несовершеннолетним правонарушителям, также имеют свою собственную превентивную цель, заключающуюся в наказании и осуждении несовершеннолетних правонарушителей, воспитании их, предотвращении совершения ими новых преступлений, в то же время обучать других несовершеннолетних уважать закон, бороться с преступностью. Необходимо выбрать вид и меру наказания, соответствующие характеру и степени совершенного правонарушения, личности несовершеннолетнего правонарушителя, отягчающим и смягчающим уголовную ответственность обстоятельствам, и требованиям предупреждения преступления, чтобы достигнуть конкретной цели наказания и обеспечить справедливость уголовного закона. [5, С. 198]

Взгляд на наказание как на инструмент борьбы с преступностью вытекает из содержания утилитарной доктрины (утилитаризм), инициированной Чезаром Беккарией. [1, С.90] Соответственно, наказанием считается боль (физическая или психическая) или определенные ограничения, которые суд назначает осужденным в целях реабилитации и профилактики. [10, С.231]

По мнению вьетнамских юристов, наказание рассматривается, исходя из двух основных характеристик. Наказание, прежде всего, рассматривается как наиболее суровое принуждение государства к правонарушителю. Таким образом, содержание наказания отождествляется с «принудительными мерами 
государства». Вторая особенность наказания отражается на его действии. Принудительный эффект наказания заключается, прежде всего, в правовых последствиях наказания. [8, С.135]

Статья 98 Уголовного кодекса 2015 года предусматривает четыре наказания, применяемые к несовершеннолетним правонарушителям: предупреждение; штраф; исправление, не связанное с лишением свободы; и лишение свободы. При этом лишение свободы является самым суровым наказанием, назначаемым несовершеннолетним правонарушителям. Четыре типа наказания ранжируются по уровню суровости. Уголовный кодекс не предусматривает дополнительные наказания в отношении несовершеннолетних правонарушителей, поэтому все эти четыре наказания являются основными. Эти наказания ничем не отличаются от аналогичных видов наказания, которые применяются к взрослым правонарушителям. В связи с психотическими особенностями, физиологией несовершеннолетних и основной целью наказания в отношении несовершеннолетних (воспитание и помощь им в исправлении своих ошибок), условия и уровни строгости наказания отличаются от таковых у взрослых. Статья 91 Уголовного кодекса 2015 года предусматривает, что лица, не достигшие 18-летнего возраста, не подлежат пожизненному лишению свободы или смертной казни.

Предупреждение является наиболее мягким видом наказания в отношении с несовершеннолетними. Предупреждение не нанесет осужденным правовые ограничения, и не связывается с физическими и имущественными правами, выгодами, а лишь причиняет психический вред. Лица, подлежащие наказанию в виде предупреждения, должны нести осуждение государства за свои преступные деяния. Поэтому наука уголовного права определяет предупреждение как «публичное порицание государства, объявленное судом осужденному». Лицо, подлежащее предупреждению, имеет судимость на срок не более 1 года (пункт 2 статьи 64 действующего Уголовного кодекса). Данное наказание вряд ли может причинить ущерб имущественным отношениям или определенные физические ограничения правонарушителям. В целях повышения роли этого наказания в воспитании правонарушителей необходимо уведомлять об этом учреждения, общественные организации и местные органы власти, где человек учится, работает и проживает. Несовершеннолетние правонарушители, подлежащие предупреждению, освобождаются от судимости через шесть месяцев после вынесения приговора в суде с условием не совершения нового преступления. Этот вид наказания является высоко образовательным, в 
основном поражая сознание и дух нарушителя. Поэтому это наказание должно в большей степени применяться судом к несовершеннолетним правонарушителям на практике. [7, С. 205]

В соответствии со статьей 35 Уголовного кодекса 2015 года общие принципы применения штрафов заключаются в следующем:

1. «Штраф применяется в качестве основного наказания в следующих случаях:

a) совершить преступления небольшой и средней тяжести, предусмотренные настоящим Кодексом;

b) совершить тяжкие нарушения против порядка ведения хозяйства, окружающей среды, общественного порядка, общественной безопасности и некоторые другие преступления, предусмотренные настоящим Кодексом.

2. Штраф применяется в качестве дополнительного наказания для лиц, совершивших коррупцию, наркотические или иные преступления, предусмотренные настоящим Кодексом.

3. Штраф назначается исходя из характера и степени опасности преступления, и при этом учитывает материальное положение правонарушителя, колебание цен, но не должен быть ниже 1000000 донгов.

4. Назначение штрафа коммерческим юридическим лицам, совершившим преступления, предусматривается статьей 77 настоящего Кодекса» [3, ст.35]

Статья 99 предусматривает следующие положения о штрафе для несовершеннолетних: «Штраф является основным наказанием для лица в возрасте от 16 до 18 лет, если у него или нее есть собственный доход или имущество. Размер итрафа для лища в возрасте от 16 до 18 лет, совершившего преступление, составляет не более половины размера штрафа, установленного законом».

Исходя из вышеуказанных положений, нарушитель подлежит штрафу в качестве основного наказания, если он подпадает под действие пункта 1 статьи 35 , и в качестве дополнительного наказания, если он подпадает под пункт 2 статьи 35, но штраф применяется только в качестве основного наказания для несовершеннолетнего правонарушителя в возрасте от 16 до 18 лет, если у него есть собственный доход или имущество. На несовершеннолетних правонарушителей в возрасте до 16 лет штраф не налагается.

Уголовный кодекс 2015 года (изменен и дополнен в 2017 году) также рассматривает применение исправления, не связанного с лишением свободы в 
качестве наказания несовершеннолетним. Если раньше, в Уголовном кодексе 1999 года, наказание в виде исправления, не связанного с лишением свободы, применялось только к случаям преступлений небольшой и средней тяжести, то теперь оно также предусмотрено за тяжкие преступления (ст. 100 УК 2015 года). «Исправление, не связанное с лишением свободы, применяется к лицам в возрасте от полных 16 до 18 лет, совершившим тяжкие преступления по неосторожности или преступления небольшой и средней тяжести, или лицам в возрасте от полных 14 до 16 лет, совершившим тяжкие преступления.» Такие положения направлены на институционализацию духа Постановления Политбюро No 49-NQ/TW «O стратегиях судебной реформы до 2020 года» в направлении сокращения сроков тюремного заключения, расширения применения штрафов и исправления, не связанного с лишением свободы, за определенные виды преступления для лиц в возрасте до 18 лет, совершивших преступления во Вьетнаме. [6]

Исправление, не связанное с лишением свободы, - это наказание, налагаемое на лицо, которое совершило преступление небольшой и средней тяжести, предусмотренное Уголовным кодексом, считая, что нет необходимости лишать осужденного свободы, без необходимости изолировать правонарушителя от общества, а передать его органу, организации, где человек работает; или местному самоуправлению, где оно проживает, для надзора и образования в течение периода от 6 месяцев до 3 лет. Исправление, не связанное с лишением свободы, является основным наказанием. Исправление более суровое, чем штраф и предупреждение, но более мягкое, чем лишение свободы. Продолжительность исправления, не связанного с лишением свободы, составляет от 6 месяцев до 3 лет. В частности, для несовершеннолетних правонарушителей срок исправления составляет не более половины срока, установленного законом. При применении исправления, не связанного с лишением свободы, к лицу, не достигшему 18-летнего возраста, совершившему преступление, доход этого лица не удерживается. Кроме того, следует отметить, что продолжительность исправления для лиц, не достигших 18летнего возраста, совершивших преступления, не должна превышать половины срока, установленного законом.

Привлечение к уголовной ответственности правонарушителей, не достигших 18-летнего возраста, в основном с целью воспитании и реабилитации, чтобы они осознали свои ошибки, и имели наилучшие условия для интеграции в общество. Эти цели отражают гуманитарности в уголовной 
политике Вьетнама. Это гуманитарность также выражается через правила назначения наказания в форме лишения свободы в отношении лиц в возрасте до 18 лет, которые зафиксируются в статье 101 Уголовного кодекса 2015 года следующим образом:

1. Для лии в возрасте от 16 до 18 лет, совершивших преступления, если действующим законодательством предусмотрено наказание в виде пожизненного лишения свободы или смертной казни, максимальное наказание для них не должно превышать 18 лет лишения свободы; если речь идет о лишении свободы, то максимальный срок лишения свободы не должен превышать трех четвертей срока лишения свободы, предусмотренного законом.

2. Для лии в возрасте от 14 до 16 лет, совершивших преступления, если действуюшим законодательством предусмотрено наказание в виде пожизненного литения свободы или смертной казни, максимальный срок лишения свободь не должен превымать 12 лет; если речь идет о лишении свободы, то максимальный срок лишения свободы не должен превышать половины срока лишения свободы, предусмотренного законом.

Таким образом, исходя из вышеуказанных положений закона, максимальный срок лишения свободы, назначаемый лицам, не достигшим 18летнего возраста, составляет не более 18 лет. Ближе к концу пунктов 1 и 2 этой статьи имеется словосочетание «срока лишения свободы, предусмотренного законом». Кроме того, отсутствует четкий документ, регламентирующий этот вопрос, поэтому применение наказания в виде лишения свободы на ограниченный срок для лица, не достигшего 18-летнего возраста, может вызывать различные способы понимания и применения.

Случай, когда лицо совершает много преступлений до и после исполнения 18 лет, будет регулироваться следующим образом:

- Если наказание за преступление, совершенное лицом до исполнения 18 лет, является более строгим, тогда применяется наказание в виде лишения свободы на срок как для лица, не достигшего 18 лет;

- Если наказание за преступление, совершенное после 18-летнего возраста, является более строгим, тогда применяется наказание за преступление, совершенное после 18-летнего возраста.

В этом случае, если лицо совершает преступление до и после достижения 18-летнего возраста, наказанием за преступление, совершенное после 18- 
летнего возраста, является смертная казнь, оно будет подлежать смертной казни.

Таким образом, положения Уголовного кодекса Вьетнама 2015 г. о применении наказаний к несовершеннолетним изменились в более благоприятную для этой группы субъектов сторону. Это один из вопросов, который всегда привлекает внимание государства в процессе судебной реформы. В то же время эти гуманитарные изменения также отражают реакцию Вьетнама на международные тенденции.

\section{Список литературы}

1. Беккариа Ч. О преступлениях и наказаниях / сост. и предисл. В. С. Овчинского. М., 2004.

2. Кант И. Метафизика нравов. Сочинения в шести томах. Том 4. 11. М., 1965.

3. Bộ luật Hình sự 2015

4. Đỗ Bá Cở (2002), Người chưa thành niên phạm tội và các giải pháp phòng ngừa của lực lượng Cảnh sát nhân dân trong tình hình hiện nay, Đề tài khoa học cấp Bộ, Nxb. Công an nhân dân, Hà Nội.

5. Lê Cảm (2005), Sách chuyên khảo Sau đại học: Những vấn đề cơ bản trong khoa học Luật hình sự, Nhà xuất bản Đại học Quốc gia, Hà Nội.

6. Nghị quyết số 49-NQ/ TW của Bộ Chính trị về Chiến lược cải cách tư pháp đến năm 2020

7. Nguyễn Xuân Yêm (2004), Phòng ngừa thanh, thiếu niên phạm tội, trách nhiệm của gia đình, nhà trường và xã hội, Nxb Công an, Hà Nội.

8. Tổng cục Xây dựng lực lượng Công an nhân dân (2011), Giáo trình Luật Hình sự Việt Nam, Nhà xuất bản Công an nhân dân, Hà Nội.

9. Từ điển Bách khoa Công an nhân dân Việt Nam năm 2005.

10. Trường Đại học Luật Hà Nội (2009), Giáo trình Luật Hình sự Việt Nam (Tập 1,2), Nhà xuất bản Công an nhân dân, Hà Nội. 